\title{
PAKAIAN ADAT KE PURA PADA GENERASI REMAJA HINDU DI DESA SARI MEKAR (PERSPEKTIF SOSIAL, BUDAYA DAN RELIGIUS)
}

\author{
Ni Nyoman Sariyani \\ STKIP Agama Hindu Singaraja, Singaraja, Indonesia \\ Email: sariyani123@gmail.com
}

\begin{abstract}
Abstrak
Penelitian ini memiliki tujuan untuk mengetahui: 1) jenis pakaian adat ke pura pada generasi remaja Hindu di desa Sari Mekar; 2) pakaian adat ke pura pada generasi remaja Hindu di desa Sari Mekar dalam perspektif sosial; 3) pakaian adat ke pura pada generasi Remaja Hindu di desa Sari Mekar dalam perspektif budaya; 4) pakaian adat ke pura pada generasi Remaja Hindu di desa Sari Mekar dalam perspektif religius. Penelitian ini adalah penelitian deskriptif kualitatif dengan menggunakan metode penelitian, yaitu: 1) penentuan informan dengan menggunakan dua metode yaitu Purposive Sampling dan Snowball Sampling, 2) teknik pengumpulan data yang terdiri dari teknik observasi, wawancara, dan studi dokumen, 3) metode keabsahan data yang terdiri dari uji kredibilitas data, uji transibilitas data, uji reliabilitas data dan uji objektifitas data, 4) analisis data.

Hasil penelitian ini adalah sebagai berikut: 1) jenis pakaian adat ke pura di desa Sari Mekar dapat dikelompokkan menjadi dua yaitu berdasarkan kelengkapan pakaiannya yang terdiri dari pakaian adat nista atau pakaian adat yang belum lengkap yang terdiri dari kamen, selendang dan baju kaos untuk wanita serta kamen, selendang, baju kaos atau kemeja dan udeng untuk laki-laki, pakaian adat madya atau pakaian adat yang sudah lengkap secara filosofi yang terdiri dari kamen, sabuk, kebaya dan selendang serta rambut harus dipusung untuk wanita serta kamen, saput, selendang dan udeng untuk laki-laki. Dan pakaian adat utama atau payas agung yang merupakan pakaian adat yang sudah lengkap secara asesoris serta berdasarkan jenis kelamin; 2) pakaian adat ke pura pada generasi remaja Hindu di desa Sari Mekar dalam perspektif sosial dapat dilihat dari pakaian adat yang dipakai. Pakaian adat juga dapat membedakan status sosial seseorang di masyarakat; 3) pakaian adat ke pura pada generasi Hindu di desa Sari Mekar dalam perspektif budaya dapat dilihat dari model pakaian adat yang dipakai. Pemilihan model pakaian adat ke pura dari yang sederhana sampai dengan modern baik berdasarkan jenis, motif serta model pakaian adat; 4) pakaian adat ke pura pada generasi Hindu di desa Sari Mekar dalam perspektif religius dapat dilihat dari dua aspek yaitu berdasarkan tri angga yaitu dewa angga (pakaian adat dari leher ke kepala) manusa angga (pakaian adat dari atas pusar ke leher), butha angga (pakaian adat dari bawah sampai pusar).
\end{abstract}

Kata Kunci: Pakaian Adat, Generasi Remaja Hindu, Sosial, Budaya, Religius. 


\section{PENDAHULUAN}

Pengaruh zaman global sudah merasuk pada segala aspek. Termasuk gaya hidup, mulai dari sikap, bicara, maupun dalam berbusana. Salah satu perubahan yang paling mencolok adalah soal penampilan (gaya pakaian). Gaya pakaian menjadi salah satu hal yang sangat mempengaruhi kepribadian seseorang di era globalisasi saat ini.

Mantra (1996: 1-2) mengemukakan bahwa globalisasi merupakan gejala yang tak dapat dihindarkan, tetapi sekaligus juga membuka kesempatan yang luas. Globalisasi telah membawa kemajuan besar dan perubahan-perubahan mendasar dalam kehidupan masyarakat Bali, khususnya umat Hindu yaitu terjadinya benturan kultur. Sekarang ini globalisasi bukan merupakan hal yang baru dibicarakan. Tekanan dari globalisasi yang menjadi tantangan terbesar saat ini harus dicarikan solusi.

Arus globalisasi dewasa ini memang membawa dampak terjadinya pergeseran dalam berbusana adat ke Pura oleh generasi muda Hindu di Bali. Banyak generasi muda yang kurang memahami dan juga ada yang tidak mau memahami tentang etika dalam berpakaian ke Pura. Banyak dari meraka yang memakai model kurang sesuai. Pada dasarnya berbusana tentu akan lebih baik jika disesuaikan dengan aktifitas/ kegiatan yang akan dilakukan.

Synnott (2003: 11-14), juga mengemukakan bahwa, "tubuh kita dengan bagianbagiannya dimuati oleh simbolisme kultural, publik dan privat, positif dan negatif, politik dan ekonomi, seksual, moral dan seringkali kontroversial". Berpakaian ke pura diharapkan pakaian yang bisa menumbuhkan rasa nyaman baik yang memakai maupun yang melihat, menumbuhkan rasa kesucian, dan mengandung kesederhanaan.

Sebagai generasi muda memang sudah sepatutnya mempelajari dan mampu memahami dan juga melaksanakan etika dalam berpakaian untuk persembahyangan ke Pura. Pikiranlah yang utama dalam mengantarkan bhakti kita kehadapan Ida Shang Hyang Widhi Wasa. Berpenampilan tetap cantik/ tampan, rapi dan bersih pada saat melakukan persembahyangan yang bertujuan agar perasaan nyaman muncul, sehingga persembahyangan pun bisa dilakukan dengan baik. Dan jangan lupa agar filosofis dalam berpakaian tidak dilupakan. Karena itu adalah sebuah budaya yang patut untuk dipertahankan.

Yang menjadi fokus penelitian adalah pakaian adat ke Pura pada Generasi Remaja Hindu di Desa Sari Mekar, dilihat dari sudut pandang (perspektif) sosial, budaya dan religius

\section{Tujuan Penelitian}

1) Mengetahui jenis pakaian adat ke pura pada generasi remaja Hindu di desa Sari Mekar.

2) Mengetahui bagaimana pakaian adat ke pura pada generasi remaja Hindu di Desa Sari Mekar dalam perspektif sosial.

3) Mengetahui bagaimana pakaian adat ke pura pada generasi remaja Hindu di Desa Sari Mekar dalam perspektif budaya.

4) Mengetahui bagaimana pakaian adat ke pura pada generasi remaja Hindu di Desa Sari Mekar dalam perspektif sosial religius. 


\section{Busana (pakaian) Adat ke Pura}

Pengertian busana (pakaian) dalam arti luas adalah suatu benda kebudayaan yang sangat penting untuk hampir semua suku bangsa di dunia. Menurut KBBI (1990: 140) busana adalah pakaian yang lengkap (yang indah-indah) dan mulia; busana tidak perlu mewah. Busana (pakaian) adat ke pura dapat diartikan pakaian yang secara khusus dibuat dan digunakan untuk mengikuti kegiatan di Pura.

Pakaian adalah menyimbolkan manusia, sebuah topeng dan suatu petunjuk tentang jabatan, tingkat, status, tetapi bukan identifikasi dengan suatu bagian dari pengada hakiki (Dillistone: 2002:80). Pakaian atau busana dikatakan sebagai suatu benda kebudayaan yang sangat penting untuk hampir semua suku bangsa di dunia (Artini 2013:3).

Dalam salah satu Dharma Wacana Ida Pedanda Gede Made Gunung (2013) mengatakan "bahwa pakaian itu merupakan produk budaya manusia, sehingga Agama Hindu tidak menyeragamkan pakaian penganutnya karena kitab suci agama Hindu adalah wahyu Tuhan bukan produk manusia yang mengayomi, mengangkat, dan memaknai budaya lokal, walaupun demikian Agama Hindu mengajarkan susila".

\section{Generasi Remaja Hindu}

Remaja adalah yang memiliki usia antara 16 tahun sampai dengan 20 tahun (Sarwono, 2012:8). Generasi remaja Hindu adalah suatu generasi penerus yang nantinya akan meneruskan segala sesuatu yang diwariskan oleh generasi yang terdahulunya. Entah itu budaya, adat, tradisi dan agama Hindu.

\section{METODE}

\section{Teori Gender}

Teori gender diturunkan dari pemikiran-pemikiran dan teori-teori sosial. Dalam teori gender dikenal dua aliran teori, yaitu teori nurture dan teori nature. Menurut teori nurture adanya perbedaan perempuan dan laki-laki pada hakekatnya adalah bentukan masyarakat melalui konstruksi sosial budaya, sehingga menghasilkan peran dan tugas yang berbeda.

Menurut teori nature, adanya perbedaan perempuan dan laki-laki adalah kodrati, sehingga harus diterima apa adanya. Perbedaan biologis itu memberikan indikasi dan implikasi bahwa diantara kedua jenis tersebut memiliki peran dan tugas yang berbeda. Ada peran dan tugas yang dapat dipertukarkan, tetapi ada tugas yang memang berbeda dan tidak dapat dipertukarkan secara kodrat alamiahnya.

\section{Teori Religi}

Menurut Harun Nasution (1987: 9), bahwa asal kata religi adalah relegere yang mengandung arti mengumpulkan dan membaca. Pengertian demikian itu juga sejalan dengan isi agama yang mengandung kumpulan cara-cara mengabdi pada Tuhan yang terkumpul dalam kitab suci yang harus dibaca. Menurut pendapat lain, kata itu berasal dari kata religare yang berarti mengikat. Ajaran-ajaran agama memang mempunyai sifat mengikat bagi manusia. Dalam agama selanjutnya terdapat pula dari ikatan roh manusia dengan Tuhan, dan Agama lebih lanjut lagi memang mengikat manusia dengan Tuhan.

\section{Teori Simbol}

Manusia yang berinteraksi dengan lingkungan hidupnya tidak bisa lepas dari simbol, karena simbol mampu mengungkapkan sesuatu dalam pikirannya. Simbol dapat memberikan arahan bagi perhatian orang dalam pemilihan alat-alat tertentu atau penentuan cara tertentu yang dipakai untuk mencapai tujuannya. Selain itu, simbol-simbol dapat membangun emosi serta mendorong orang untuk bereaksi (Adam Wolanin, 1978: 39-42).

Ada tiga macam dimensi arti simbol, yaitu: 1) eksegenik, artinya dimensi simbol yang diberikan oleh informan kepada peneliti. 2) operasional, artinya simbol dilihat tidak hanya 
dari penafsiran secara verbal melainkan juga apa yang dapat ditangkap oleh pengamat atau peneliti. 3) posisional, yaitu simbol yang dipahami dalam konteks relasi dengan simbol lainnya. Simbol sangat bermanfaat bila dipandang dari sudut yang benar, simbol akan memainkan suatu bagian yang sangat penting dalam kehidupan material, demikian juga dalam kehidupan spiritual, walaupun kelihatan sangat sederhana dan remeh akan tetapi penggunaan simbol sangat berguna dan efektif

\section{Teori Makna}

Makna adalah bagian yang tidak terpisahkan dari sematik dan selalu melekat dari apa saja yang kita tuturkan. Pateda (2001:79) menyatakan bahwa istilah makna merupakan kata-kata dan istilah yang membingungkan. Makna tersebut selalu menyatu pada tuturan kata maupun kalimat.

Menurut Ullman (dalam Pateda, 2001) bahwa makna adalah hubungan antara makna dengan pengertian. Dalam hal ini Ferdinand de Saussure (dalam Chaer, 1994) mengungkapkan pengertian makna sebagai pengertian atau konsep yang dimiliki terdapat pada suatu tanda linguistik. Dimana tanda tersebut digunakan dalam bahasa teks dan konteks secara logis, interaksional dan aktual.

\section{Teori Struktural Fungsional}

Menurut Usman (2004: 63) bahwa teori struktural fungsional sistem sosial hanya dilihat sebagai yang ditandai oleh keseimbangan-keseimbangan dan bagian-bagian dan sistem tersebut saling bergantung satu sama lain, tetapi juga sistem sosial dianggap terdiri dari individu-individu yang saling berhubungan (membentuk relasi sosial), agar suatu sistem terintegrasi dan stabil, individu-individu yang menjadi bagian dan sistem tersebut memberi dukungan keberadaan nilai-nilai umum yang berlaku di dalamnya.

Kajian struktural adalah untuk menjelaskan dunia pengalaman dan memahami rasionalitas dasar yang menyangga dunia fenomena. Hal tersebut dapat tercapai dengan penyingkapan amanat yang sering bersifat singkat, padat dan terkodekan yang muncul sebagai akhir transformasi rasionalitas ini, yakni kaidah struktural dasar dalam mengajukan penjelasan, terdiri atas kategori-kategori dan hubungan logis yang terbentuk dan kecenderungan manusia untuk memandang semesta sehubungan koinsidensi bentuk (Kaplan, 1999: 245). Globalisasi telah menimbulkan dampak dan pengaruh yang begitu besar dalam dimensi kehidupan manusia, karena globalisasi merupakan proses internasionalisasi seluruh tatanan masyarakat khususnya generasi remaja. Dalam hal ini adalah pada saat memakai pakaian adat sembahyang seharusnya sesuai dengan segi sosial, budaya dan religius. Hal ini dapat dikaji memakai beberapa teori yaitu teori gender, teori religi, teori simbol, teori makna dan teori struktual fungsional.

\section{HASIL DAN PEMBAHASAN}

\section{Gambaran Umum Lokasi Penelitian}

Desa Sari Mekar merupakan salah satu desa/ kelurahan yang berada di Kecamatan Buleleng, Kabupaten Buleleng. Desa Sari Mekar memiliki luas wilayah 232,12 Ha.

Wilayah Desa Sari Mekar memiliki batas-batas, yaitu: sebelah utara berbatasan dengan Kelurahan Kendran, sebelah selatan berbatasan dengan desa Padangbulia, sebelah barat berbatasan dengan Lingkungan Bakung, Bantang Banua, Kelurahan Liligundi, sebelah timur berbatasan dengan Desa Petandakan. Desa Sari Mekar terdiri dari tiga dusun, yaitu: 1) dusun Dajan Margi, 2) dusun Delod Margi, 3) dusun Lebah Mantung. 


\section{Pakaian Adat Ke Pura Pada Generasi Remaja Hindu Di Desa Sari Mekar}

1. Jenis Pakaian Berdasarkan Kelengkapan

Berdasarkan kelengkapannya jenis pakaian adat yang dipakai remaja di Desa Sari Mekar terbagi menjadi tiga kelompok yaitu pakaian adat nista, madya dan utama (agung) (Agung, 1997:11).

\section{a. Pakaian Adat Nista}

Pakaian adat nista merupakan pakaian adat yang digunakan untuk melakukan kegiatan-kegiatan upacara namun pakaian adat ini tidak dipergunakan untuk persembahyangan ke pura (pakaian adat yang belum lengkap). Pakaian adat nista dipergunakan untuk kegiatan-kegiatan tertentu seperti ngayah atau kerja bakti untuk membersihkan lingkungan pura atau tempat-tempat persembahyangan, dan juga dipergunakan pada saat maturan canang sehari-hari.

Hal tersebut sejalan dengan penjelasan Agung (1997:50-51) yang menyatakan bahwa pakaian adat nista untuk ngayah terdiri dari:

$\checkmark$ Busana lanang terdiri dari:

- Alas kaki

- Kain (kamen/ wastra), sebaiknya berupa kain lembaran (bukan kain sarung), agar mudah dibuatkan kancut, kalau diperlukan kancut bisa ditarik dan dijepit di pinggang (mebulet ginting). Hal ini dilakukan, misalnya pada saat mencari reramon, ngejuk celeng atau kegiatan sejenis, sehingga kain/ kamen yang digunakan tidak menghalangi gerak pemakainya.

- $\quad$ lkat pinggang

- Selempot/ sesenteng

- Baju untuk ngayah

- Pakaian dalam

- Udeng/ destar (bukan songket)

$\checkmark$ Busana wanita (istri)

- Alas kaki

- Kain (kamen/ wastra)

- Sabuk (stagen, streples)

- Pakaian dalam

- Baju kebaya

- Sesenteng

\section{b. Pakaian Adat Madya}

Pakaian adat madya merupakan pakaian adat yang dipergunakan untuk persembahyangan. Pakaian adat madya termasuk pakaian adat yang sudah lengkap secara filosofi dimana pakaian adat madya untuk wanita di bawahnya menggunakan kamen yang dilipat dari kanan ke kiri yang merupakan simbol dari sakti, kemudian dililit dengan sabuk atau stagen yang berfungsi untuk menjaga dan mengendalikan emosi, baju kebaya dan yang terakhir selendang. Untuk bagian kepala rambut harus diikat.

Sedangkan untuk pria di bawahnya menggunakan kamen yang dililit dari kiri ke kanan yang merupakan simbol dari pemegang dharma, kemudian saput yang merupakan simbol pengendalian, kemudian selendang kecil yang berfungsi untuk mengendalikan hal-hal buruk, baju safari dan yang terakhir menggunakan udeng.

Hal tersebut sejalan dengan penjelasan Sudiana dan Artha (2006:44) yang menyatakan bahwa pakaian adat madya terdiri dari:

a. Busana madya (sedang)

Untuk pria

- Baju/ destar

- Kampuh/ selempot

- Kain panjang

- Sabuk

- Alas kaki 


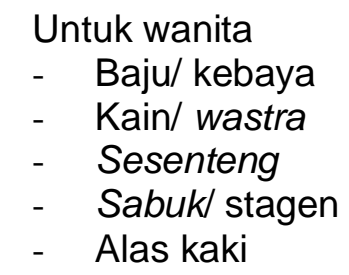

\section{c. Pakaian Adat Utama}

Pakaian adat utama sering disebut dengan payas agung, karena pakaian adat utama merupakan pakaian yang paling mewah (pakaian lengkap berdasarkan aksesoris).Ada beberapa desa yang memiliki pakaian adat utama yang dipakai pada saat upacara keagamaan.

\section{Pakaian Adat Remaja Sari Mekar Berdasarkan Jenis Kelaminnya}

a. Pakaian adat lelaki

\section{Memiliki ikat kepala, yang dalam bahasa Bali disebut Udeng}

Udeng adalah penutup kepala dari kain yang dipakai untuk kegiatan persembahyangan, tidak jarang juga untuk aktivitas sehari-hari. Udeng yang digunakan untuk acara keagamaan adalah udeng putih, sedangkan udeng yang dipakai untuk kegiatan sehari-hari adalah udeng yang memiliki motif batik. Bentuk udeng yang unik dengan simpul di bagian tengah adalah simbol bahwa pemakainya harus berpikir jernih dan memusatkan pikirannya saat bersembahyang.

\section{Baju}

Baju pada perlengkapan pakaian adat Bali adalah sebuah model baju tertutup yang memiliki model hampir mirip dengan baju safari. Baju adalah pengganti saput sedada (jaman dahulu), merupakan penutup dada dan perut simbolisasi menutup ego dan kesombongan. Selain baju safari, ada juga model baju lain untuk laki-laki yang dikenakan pada saat persembahyangan, yaitu yang disebut baju yoko, baju yang sedang ngetren saat ini baik itu yang berlengan pendek maupun yang berlengan panjang. Meskipun demikian, pada prinsipnya baju yang dikenakan tidak memiliki aturan khusus, yang diutamakan adalah bersih, rapi dan sopan.

\section{Kain Kamen, yaitu kain yang digunakan sebagai pengganti celana}

Pakaian adat Bali tidak mengenakan celana seperti pada umumnya sebagai bawahan. Celana diganti dengan kamen, yaitu sejenis kain sepanjang 2 meter dan lebar 1 meter. Kain ini diikatkan di pinggang secara melingkar dari kiri ke kanan. Ikatan tersebut melambangkan Dharma. Pemakaian pada tepi bawah harus sejengkal dari telapak kaki dengan disertai bentuk lancip pada ujung yang menghadap ke bawah, menyentuh tanah, adalah sebuah bentuk kehormatan pada ibu pertiwi.

\section{Mengunakan sabuk dan berbagai perhiasan lainnya}

Selendang kecil dipakai untuk melengkapi dan menguatkan kamen dan saput. Ikatan yang diterapkan adalah ikatan dengan menggunakan simpul hidup yang diletakkan di posisi sebelah kanan. Cara mengikat tersebut memiliki arti bahwa pria Bali harus dapat mengendalikan semua hal buruk dari segala aktivitasnya.

Pakaian adat Bali untuk pria pada acara-acara tertentu juga dilengkapi dengan aksesoris lain seperti keris, kemeja dan jas.

\section{Saput (Kampuh)}

Saput merupakan kain penutup bagian bawah yang dipakai setelah kamen. Cara memakainya adalah dengan cara saput diikatkan pada pinggang secara melingkar berlawanan arah jarum jam. Tujuan utama penggunaan saput ini adalah untuk menutupi lekuk tubuh dan aurat. Kain penutup ini paling sering dikenakan pada saat acara persembahyangan.

\section{b. Pakaian adat perempuan}

\section{Memakai Sanggul}

Cara menata rambut lengkap dengan hiasannya memiliki aturan khusus bagi wanita Bali. Setidaknya ada 3 jenis model tata rambut wanita atau sanggul yang bisa diterapkan, 
yaitu pusung kekupu, pusung gonjer, dan pusung tagel. Pusung kekupu atau biasa disebut juga pusung podgala digunakan khusus oleh wanita yang menyandang status janda, pusung gonjer dikenakan khusus untuk wanita yang belum menikah atau lajang, dan pusung tagel dikenakan khusus untuk kalangan wanita yang sudah menikah

\section{Kebaya}

Kebaya yang digunakan pada pakaian adat perempuan Bali adalah kebaya yang memiliki motif sederhana dengan warna cerah. Pemilihan kebaya dengan model seperti itu dapat menonjolkan sisi keanggunan dan kecantikan wanita Bali. Untuk keperluan persembahyangan, kebaya yang dikenakan harus sopan, rapi dan juga bersih.

\section{Kamen}

Untuk bagian bawah, pakaian adat Bali bagi wanita juga dilengkapi dengan kamen tetapi ikatan kamen melingkar dari kanan ke kiri (searah jarum jam) yang bermakna bahwa wanita sebagai sakti bertugas sebagai penyeimbang. Kain ini dikenakan untuk menutupi tubuh bagian bawah hingga sebatas satu telapak tangan dari lutut. Batasan itu diatur untuk wanita Bali agar tetap leluasa ketika bergerak melangkah namun tetap terlihat anggun dan sopan.

\section{Selendang (Senteng)}

Pada umumnya, wanita Bali juga mengenakan senteng atau selendang yang disampirkan pada bahu. Pemakaian senteng memiliki makna filosofis bahwa wanita Bali harus ingat ajaran dharma dan siap mendidik putra putrinya kelak agar patuh terhadap orang tua.

\section{Sabuk}

Sabuk pada pinggang ini juga bertujuan untuk menguatkan ikat kamen. Wanita Bali mengenakan selendang bulang pasang dalam pakaian adat mempunyai makan filosofis yaitu sebuah pesan agar wanita Bali dapat menjaga rahimnya dan dapat mengendalikan tingkah lakunya dari segala keburukan.

\section{Mengenakan perhiasan ataupun asesoris lainnya}

Dalam penggunaan pakaian adat Bali, sering kali kita melihat khususnya para wanita mengenakan berbagai perhiasan, baik berupa kalung, anting atau sumpel dan juga asesoris lain. Mereka juga terkadang menyelipkan bunga cempaka putih atau kuning, atau bunga kamboja di telinga dan rambut. Hal itu dikenakan bukan hanya untuk keindahan saja, tetapi mempunyai maksud tertentu, yaitu sebagai penghormatan bagi tamu yang telah berkunjung.

\section{Pakaian Adat Ke Pura Pada Generasi Remaja Hindu Di Desa Sari Mekar Dalam Perspektif Sosial}

Secara sosial adanya keseragaman berpakaian ini bisa dimaknai sebagai cara untuk membedakan kelas atau kelompok remaja ini dengan pemedek yang lainnya. Dengan adanya perbedaan itu diharapkan mereka memiliki tanggungjawab dan juga sikap yang lebih baik karena secara sosial mereka adalah kelompok remaja terpilih.

Selain itu secara sosial pemilihan pakaian juga bisa dimaknai sebagai posisi sosial ekonomi. Karena jika ada masyarakat atau remaja yang memakai pakaian yang mahal tentunya itu bisa dimaknai memiliki struktur sosial yang berbeda.

Selain itu pemilihan warna juga bisa dimaknai berbeda dalam kontek sosial seperti pemilihan warna putih-putih secara keseluruhan dari baju sampai kamen itu bisa bermakna sosial adalah pemangku. Selain itu perbedaan pakaian juga dimaknai untuk membedakan jabatan sosial yang diampu.

\section{Pakaian Adat Ke Pura Pada Generasi Remaja Hindu Di Desa Sari Mekar Dalam Perspektif Budaya}

Saat ini banyak sekali model pakaian adat yang muncul seperti kamen, kebaya, udeng serta baju safari atau pakaian adat pria. Mengingat berpakaian adat ke pura merupakan ciri khas agama Hindu yang ada di Provinsi Bali, memang terlihat anggun jika 
seseorang ke pura dengan pakaian sedemikian rupa dan menggunakan aksesoris yang berlebihan.

Dalam perspektif budaya setiap kegiatan adat Bali dan agama Hindu harus memakai pakaian adat Bali, ada aturan berupa awig-awig atau himbauan. Pemakaian pakaian adat termasuk dalam budaya Hindu khususnya yang berada di Bali dan di Indonesia pada umumnya. Dengan melestarikan pakaian adat Bali, maka kebudayaan Hindu Bali akan tetap terjaga dan tetap lestari.

\section{Pakaian Adat Ke Pura Pada Generasi Remaja Hindu Di Desa Sari Mekar Dalam Perspektif Religius}

1. Jenis pakaian yang dipakai di bagian dewa angga

Pakaian pada bagian dewa angga merupakan pakaian dari leher ke kepala, adapun yang termasuk dalam bagian dewa angga untuk laki-laki adalah udeng. Pada saat melakukan persembahyangan udeng yang dipakai berwarna putih. udeng secara umum dibagi tiga yakni: Udeng jejateran (udeng untuk persembahyangan), Udeng dara kepak (dipakai oleh raja), Udeng beblatukan (dipakai oleh pemangku).

Sedangkan pakaian dewa angga untuk wanita adalah sanggul, dimana dalam agama hindu ada 3 bentuk sanggul yang dipergunakan, diantaranya adalah pusung gonjer untuk wanita yang belum menikah, pusung tagel untuk wanita yang sudah menikah dan pusung kekupu untuk wanita yang sudah berstatus janda.

\section{Jenis pakaian yang dipakai di bagian manusa angga}

Pada bagian manusa angga yang utama yaitu penggunakan baju (kwaca) dengan syarat bersih, rapi dan sopan. Baju pada saat busana adat terus berubah-ubah sesuai dengan perkembangan. Pada saat ke pura harus menunjukan rasa syukur kita, rasa syukur tersebut diwujudkan dengan memperindah diri. Jadi pada bagian baju sebenarnya tidak ada patokan yang pasti.

Pakaian pada bagian manusa angga adalah pakaian dari atas pusar sampai dengan leher, yang termasuk pada bagian manusa angga adalah selendang, selendang yang dipergunakan lelaki untuk mengikat kamen dan kampuh agar lebih kuat. Sebagai simbol agar para lelaki bisa mengendalikan hal buruk. Sedangkan wanita menggunakan selendang setelah memakai kebaya hal ini menyimbolkan agar para wanita dapat mengendalikan tingkah lakunya. Kemudian baju kebaya untuk wanita dan baju safari untuk lelaki.

\section{Jenis pakaian yang dipakai di bagian butha angga}

Pakaian pada bagian butha angga adalah pakaian yang dipakai dari pusar ke bawah. Adapun yang termasuk butha angga adalah kamen, antara penggunaan kamen lelaki dan perempuan ada perbedaan dalam pemakaiannya yaitu lelaki ikatannya melingkar dari kiri kekanan sebagai lambang dharma serta memiliki lancingan sebagai lambang kejantanan dan kekuatan.

Untuk menutupi kejantanan itu maka ditutupi dengan saputan (kampuh).Tinggi saputan kira-kira satu jengkal dari ujung kamen, selain untuk menutupi kejantanan, saputan juga berfungsi sebagai penghadang musuh dari luar. Saputan melingkar berlawanan arah jarum jam (prasawya). Kemudian dilanjutkan dengan menggunakan selendang kecil (umpal) yang bermakna kita sudah mengendalikan hal-hal yang buruk.

Sedangkan untuk wanita ikatannya melingkar dari kanan ke kiri, hal ini melambangkan sakti dan sebagai penyeimbang. Untuk menguatkan ikat kamen wanita Hindu menggunakan bulang pasang dan sekarang yang sering digunakan adalah stagen. Bulang pasang dalam pakaian adat bali wanita memiliki filosofi bahwa wanita Bali dapat menjaga rahimnya dan mengendalikan tingkah lakunya dari segala keburukan.

Selain pembagian memakai konsep tri angga makna religius pakaian adat remaja ke pura bisa dilihat dari pemilihan warna pakaian yang dipakai. Secara umum warna pakaian yang dipilih ketika sembahyang adalah berwarna putih dan kuning. Warna putih melambangkan kesucian sedangkan warna kuning melambangkan kebijaksanaan. Namun 
dalam perkembangannya ada juga remaja yang memakai warna-warna lain selain warna putih dan kuning, seperti warna merah, hijau orange dan warna-warna yang lain.

\section{Simpulan dan Saran}

Berdasarkan uraian hasil penelitian tersebut, maka dapat disimpulkan bahwa:

1. Jenis pakaian yang dipakai oleh remaja di Desa Sari Mekar secara umum dapat dikelompokkan menjadi dua yaitu berdasarkan kelengkapan pakaiannya yaitu pakaian adat nista, pakaian adat madya serta pakaian adat utama. Dan berdasarkan jenis kelamin yaitu pakaian adat untuk lelaki dan pakaian adat untuk wanita. Pakaian adat nista merupakan pakaian adat yang belum lengkap dimana pakaian adat nista sering dipakai pada saat ngayah untuk membersihkan areal persembahyangan, paruman adat dan untuk maturan canang sehari-hari. Adapun pakaian adat nista terdiri dari kamen, selendang dan baju kaos untuk wanita, sedangkan untuk pria menggunkan kamen, selendang, baju kaos atau kemeja serta udeng. Pakaian adat madya merupakan pakaian yang sudah lengkap secara filosofi, pakaian ini dipakai untuk upacara persembahyangan dan pakaian, yang terdiri dari kamen, sabuk, kebaya, selendang dan bagian kepala harus diikat/ dipusung. yang terakhir adalah pakaian adat utama yang sering disebut dengan payas agung yang merupakan pakaian adat yang sudah lengkap secara aksesoris.

2. Dilihat dari perspektif sosial pakaian adat ke pura pada generasi remaja di desa Sari Mekar dapat dilihat dari pakaian adat truna truni desa Sari Mekar serta pakaian adat juga membedakan status sosial seseorang di masyarakat. Status sosial yang dimaksud misalnya bertugas sebagai truna jangkong dan truni pesaren menggunakan pakaian adat yang sudah disepakati misalkan kamen, selendang, kebaya, saput maupun udeng. Pemangku memakai pakaian yang serba putih, prajuru adat, sekaa gong dan pecalang yang menggunakan baju berwarna merah dengan saput dan udeng yang berwarna poleng.

3. Dilihat dari perspektif budaya pakaian adat ke pura pada generasi remaja Hindu di desa Sari Mekar dapat dilihat dari pemilihan model pakaian sembahyang yang dipakai oleh remaja desa Sari Mekar. Pemilihan model pakaian sembahyang dari yang sederhana sampai dengan model modifikasi yang trend saat ini, baik dari jenis, motif serta model pakaian adat. Dan model kebaya yang paling populer di desa Sari Mekar adalah model kebaya Kartini.

4. Dilihat dari perspektif religius pakaian adat ke pura pada generasi remaja di Desa Sari Mekar dapat dilihat dari dua aspek yaitu berdasarkan tri angga yaitu dewa angga (dari leher ke kepala), manusa angga (dari atas pusar ke leher) dan butha angga (dari bawah sampai pusar) dan pemilihan warna pakaian ketika sembahyang

\section{Saran}

Adapun saran-saran yang dapat penulis sampaikan dalam penelitian ini antara lain:

1. Bagi perangkat desa khususnya Desa Sari Mekar mampu menghimbau seluruh masyarakatnya agar turut mengajegkan Bali salah satunya dengan memakai pakaian adat ke Pura dengan sopan dan sesuai dengan etika berpakaian adat.

2. Bagi generasi remaja desa Sari Mekar diharapkan turut serta dalam melestarikan kebudayaan Hindu khususnya berpakaian adat ke pura sehingga warisan budaya tetap lestari dan tetap ajeg.

3. Bagi pihak terkait, yaitu pihak Departemen Agama khususnya di Kabupaten Buleleng dan tim penyuluh supaya memberikan penyuluhan terkait tata cara penggunaan pakaian adat ke pura agar masyarat lebih mengetahui tentang tata cara dan etika berpakaian adat ke pura yang benar. 
Jurnal Widya Sastra Pendidikan Agama Hindu, Vol. 2, No. 12019

e-ISSN : 2656-7466, p-ISSN : 1907-9559

\section{DAFTAR PUSTAKA}

Agung, A.A. Ayu Ketut. 1997. Busana Adat Bali. Denpasar: Pelawa Mas

Arikunto, Suharni. 1993. Metode Penelitian Pendidikan. Jakarta: Balai Pustaka

Artini, Ni Made Rai. 2013. Menyoroti Etika Umat Hindu "Ke Pura Berpenampilan Selebritis" Skripsi: Universitas Pendidikan Ganesha Singaraja.

Dillistone, F.W. 2002. Daya Kehuatan Simbol (The Power Of Symbol), Yogyakarta: Kanisius

Faisal, 1990.Penelitian Kualitatif. Malang. Yayasan Asah Asih Asuh

Harun Nasution. 1987. Muhammad Abduh dan Teori Rasional Mu'tazilah. Jakarta: UI Press

Hendraningrum, Retno. 2008. "Fashion dan Gaya Hidup: Identitas dan Komunikasi." Jurnal IImu Komunikasi, 32 (6), 25-32. Yogyakarta: Fakultas IImu Sosial dan IImu Politik Universitas Pembangunan Nasional Veteran Yogyakarta.

http://acaryawasu.blogspot.co.id/2012/11/tatwa-busana-adat-bali-makna-dan.html, diakses pada 1 April 2017

Jayanti, I Gusti Ngurah. 2008. "Perempuan Dalam Gaya Hidup. Kebaya dan Gaya Hidup Perempuan Bali."Kembang Rampai Perempuan Bali. -, 41-64. Denpasar: Pusat Studi Wanita Universitas Udayana.

Kaplan, 1999. Teori Budaya, Yoyakarta: Pusaka Pelajar

Koentjaraningrat. 1990. Pengantar IImu Antropologi. Jakarta: PT Rineka Cipta.

Mansoer Pateda. 2001. Sematik Leksikal. Jakarta: Rineka Cipta

Mantra, Ida Bagus, 1996. Landasan Kebudayaan Bali. Denpasar: Yayasan Dharma Sastra.

Moleong, Lexy. 2009. Metodologi Penelitian Kualitatif. Bandung: PT Remaja Rosdakarya.

Monografi Desa Sari Mekar Tahun 2016.

Nala, Ngurah dan Adia Wiratmadja.1993. Murddha Agama Hindu. Denpasar: Upada Sastra.

Sarlito W. Sarwono. 2012. Psikologi Remaja, ed. Revisi. Jakarta: Rajawali Pers

. Siandari, Apriliasti. 2013. "Makna Simbolis Pakaian Adat Pengantin Suku Sasak Lombok Nusa Tenggara Barat" Universitas Negeri Yogyakarta.

Sudiana, I Gusti Ngurah dan I Made Artha.2006. Samhita Bhisama Parisada Hindu Dharma Indonesia.Denpasar: Bimas Hindu.

Sugiyono, 2009.Metode Penelitian Pendidikan pendekata kuantitatif, kualitatif, dan R\&D, Bandung: ALFABETA

Synnott, 2003. Tubuh Sosial: Simbolisme diri dan Masyarakat. Yogyakarta: Jalasutra.

Triguna, 1997. Teori Struktural Fungsional. Jakarta: Gramedia

Usman Sunoto, 2004, Pembangunan dan Pemberdayaan Masyarakat. Yogyakarta: Pustaka Pelajar 
Jurnal Widya Sastra Pendidikan Agama Hindu, Vol. 2, No. 12019

e-ISSN : 2656-7466, p-ISSN : 1907-9559

Wolanin, SJ, Adam. 1978 Rites Ritual Symbols and Their Interpretation in Writings of Victor W. Turner: A phenomenological-theological study, Roma: Typis Pontificiae Universitas Gregorianae 